\title{
CRYSTAL-MELT \pm FLUID PHASE EQUILIBRIA VERSUS LATE-STAGE FLUID-ROCK INTERACTION IN GRANITOID ROCKS OF THE SOUTH MOUNTAIN BATHOLITH, NOVA SCOTIA: WHOLE ROCK GEOCHEMISTRY AND OXYGEN ISOTOPE EVIDENCE
}

\author{
Daniel J. Kontak*, David F. Strong \\ Department of Earth Sciences, Memorial University of Newfoundland \\ St. John's, Newfoundland AIB 385 \\ and \\ Robert Kerrich \\ Department of Geological Sciences, University of Saskatchewan \\ Saskatoon, Saskatchewan S7N OWO
}

Date Rece1ved November 16, 1987

Date Accepted March 30,1988

\begin{abstract}
The chemical and oxygen isotopic evolution of the $370 \mathrm{Ma}$, peraluminous South Mounta1n Batholith of Nova Scotia has been examined. The chemistry of early- to late-stage magmatic suites is uniform with respect to most major and trace elements, including the rare earth elements (REE). The continuity of the chemistry reflects the dominant role of me1t-crystal equilibria during progressive fractionation of the melt through the sequence granodiorite-monzograniteleucogranite (group I). However, leucogranites (group II) associated with pegmatite occurrences in the New Ross area have chemical signatures, especially their REE patterns (extreme LREE depletions and concave HREE profiles peaking at Gd-Dy), which indicate that fluid-phase equilibria played an important role in the evolution of these rocks.

Whole-rock oxygen-1sotope compositions are uniform at $10.6 \pm 0.5 \%$ ( $\mathrm{N}-14$ ) regardless of proximity to gontacts. degree of fractionation or presence of late-stage deuteric alteration. The observed variation (ca. 1.8 /oo) 1 s attributed to primary heterogeneity in the source region, and not crystal fractionation processes. Mineral separates from pegmatites indicate deviations from magmatic equilibrium based on quartz-feldspar fractionation. This 1s interpreted to reflect re-equilibration of feldspar with 1 ow temperature fluids of magmatic derivation (calculated $\delta$. 0 of the fluid is $\delta^{-10} \%$ o $)$. In contrast, one of the greisens examined records interaction with 180 enriched flulds (calculated $\delta 180$ composition of $11.5-14 \%$ for $\mathrm{T}-300-490 \mathrm{C}$ ), which were probably der1ved from the enveloping metasedimentary country rock (i.e., Meguma Group). A low 0 value $(3.6 \%$ oo) for one whole-rock sample 1ndicates that meteoric water also played a role, albeit minor, in the evolution of the batholith.
\end{abstract}

On a examine l'évolution de la chimie et des 1sotopes de 1'oxygène dans le Batholite péralumineux de South Mountain (daté à $370 \mathrm{Ma}$ ) en Nouvelle-Ecosse. Le chimisme des suites magmatiques, tant tard1ves que précoces, est uniforme en ce qui a trait a la plupart des elements majeurs et en traces, $y$ comprises les terres rares (T.R.). Cette continuité du chimisme met en lumiére le rôle prépondérant joué par les equilibres bain-cristal durant le fractionnement progressif de ce bain via la série granodiorite-monzogranite-leucogranite (groupe I). En revanche, les leucogranites du groupe II, associes aux venues pegmat1tiques dans la région de New Ross, ont des signatures chimiques (plus particulierement des spectres de terres rares extrêmement appauvris en $T$.R. légéres et montrant des profils concaves pour les T.R. lourdes avec des anomalies positives à Gd-Dy) qui mettent en evidence le rôle majeur joue par les équilibres fluide-phase dans l'évolution de ces roches.

Les compositions isotopiques de l'oxygène sur roche totale sont uniformes a $10.6 \pm 0.5 \%$ ( $/ 00$-14) peu 1mportent la proximité des contacts, le degré de fractionnement ou la présence d'alterations deutériques tardives. On attribue la variation observee (environ $1,8 \%$ ) a une heterogeneite primaire de la source et non pas aux processus de fractionnement des cristaux. Les mineraux sépares des pegmatites montrent des deviations par rapport à l'equilibre magmatique base sur le fractionnement des quartz et feldspaths, ce qui semble trahir un re-equilibrage du feldspath avec des fluides de température faible 1ssus du magma ( $\delta^{10}$ calcule du fluide est $\left.7-10, / 00\right)$. Par contre un des greisens examinés met en lumiere une interaction avec des fluldes enrichis en 180 ( $\delta 180$ calcule $11.5-14 \%$ pour $\mathrm{T}-300-400^{\circ} \mathrm{C}$ ) dérives probablement de l'encaissant metaseddmentaire (1.e.. le Groupe de Meguma). Une faible valeur du $180(3.6 \%$ en provenance d'un seul echantilion sur roche totale indique que les eaux métériques ont aussi joue un rôle, quoique mineur, dans l'évolution du batholite.

[Traduit par le journal]

\section{INTRODUCTION}

The evolution of granitold bodies involves early magmatic processes dominated by melt-crystal equilibria, which is succeeded by late-stage magmatic and post-magmatic processes in which the role of a fluid phase becomes more important as the solubility of aqueous fluids is reduced in residual me1ts and saturation occurs (e.g., Burnham, 1979).

*Present address: Nova Scotia Department of Mines and Energy, P.0. Box 1087, Halifax, Nova Scotia B3J 2X1)

MARITIME SEDIMENTS AND ATLANTIC GEOLOGY

24 . $97-110$ (1988)
The latter stage is manifested most prominentiy in the formation of pegmatites, metasomatic zones and areas of mineralization, particularly the granitophile association (e.g., Sn, W, U, L1, Be: see Strong (1981) for a general review). Because of the inevitable involvement of at least some fluid phase of variable origin (e.g., juvenile, metamorphic, meteoric) during the evolutionary history of granitoid bodies, and consequent1y some modification of magmatic mineralogy and chemistry, it is not always easy to discern the origin of alteration and mineralization in granites (e.g. Stone and Exley, 1986; Manning and Exley, 1984; 
Kontak and Corey, 1988). It is essentlal that the features characteristic of these different processes be recognized as they provide the foundation for determining the nature and origin of granitoid rocks and related mineral deposits (e.g. . see recent papers in Taylor and Strong (1985) and HHPG (1985)).

To examine this problem, we have focused our study on a suite of rocks from the eastern part of the South Mountain Batholith (SMB), where the extreme end-members, as we11 as the transitional stage, of these processes are well represented. For example, early granodiorites, representing the most primitive component of the SMB, and late-stage monzogranites, leucomonzogranites and pegmatites, representing the most evolved members, all outcrop in the eastern part of the SMB. While the magmatic and late hydrothermal processes operative within the SMB have been examined by numerous workers (e.g., McKenzie and Clarke, 1975; Logothet1s, 1984; Chatterjee and Strong, 1984; Ford and 0'Re111y. 1985) and their chemical and petrographic signatures "defined" (e.g., extreme modification of rare-earth element (REE) patterns in greisen zones: Chatterjee and Strong, 1984; Strong and Chatterjee, 1985), the transitional stage between these two extremes remains poor1y understood. For example, during the latest stage of crystallization and earliest post-magmatic stage when volatiles become increasing1y more important there will be a reequilibration of whole rock mineralogy and chemistry due to the influence of the fluid phase (e.g. Ford and 0'Reilly, 1985). It is this transitional stage which is the focus of the present study as we try to address the problem of distinguishing the boundary between crystal-melt \pm fluid versus rock-fluid equilibria.

We first discuss the petrography and chemical features of the granitic rocks in order to establish magmatic versus orthomagmatic or hydrothermal trends. The oxygen 1sotopic signatures of whole rocks and mineral separates are reported, and the results are then discussed in the context of magmatic versus hydrothermal processes and integrated with other petrological data.

\section{REGIONAL GEOLOGICAL SETTING AND EVOLUTION OF THB SOUTH MOUNTAIN BATHOLITH}

The SMB is a ca. $370 \mathrm{Ma}$, post-tectonic, peraluminous granitoid batholith which intruded Cambro-Ordovician metasedimentary rocks of the Meguma Group. Leve1 of emplacement is considered to have been $1-3 \mathrm{~kb}(1 . \mathrm{e}, 4-12 \mathrm{~km}$ ) and the chronological sequence of intrusion was granodiorite, monzogranite and leucomonzogranite. Pegmatites and mineralized leucogranite centres are locally present within the SMB. These field relationships indicate, therefore, that the formation of late-stage, fluid-rich systems was indeed an important and integral part of the evolution of this batholithic complex. Much of the late-stage fluid activity was centred in and around the New Ross area, the geology of which is summarized by O'Reiliy et al. (1982).

Previous workers have concluded from various lines of evidence that the SMB, although strong1y peraluminous in nature, did not originate by anatexis of the Meguma Group (Clarke and Muecke, 1985, and references therein). Instead, another crustal source materlal is considered the 11kely parent, with a minor contribution of Meguma Group 11thologies having occurred during the magmatic (Clarke and Halliday, 1980) and post-magmatic stages (Kub1lius, 1983). While crystal fractionation processes have generally been considered responsible for the chemical evolution of the SMB (McKenzie and Clarke, 1975; Smith et al., 1986), It has been suggested that late-stage fluid-melt-crystal equilibria were also important in controlling the distribution of at least some trace elements in the more evolved members of the SMB. For example, Clarke and Muecke (1981) have attributed the patterns and abundances of the REE in the leucomonzogranites to be partly a result of removal via an exsolved moblle fluid. However, the recent 1dentification of accessory mineral phases such as monazite and xenotime (M.A. MacDonald, personal communication, 1987) can also account for the general depletion of the LREE and MREE in the SMB (Smith et al., 1986) and, thus, the necessity of a fluid phase to account for this feature, as Clarke and Muecke (1981) advocated, is perhaps not warranted.

\section{SAMPLE LOCATIONS AND PETROGRAPHY}

Samples were selected from the eastern part of the SMB within an area that has recently been remapped (MacDonald et al., 1987). The sample localities and simplified geology of the region are shown in Figure 1. Because of the high density of pegmatite bodies and related mineralization in the New Ross area, our study was focused here. However, materlal was also selected from other localities in the eastern part of the SMB for comparative purposes. In addition, samples from both close to and well removed from contacts with metasedimentary rocks were also collected in order to evaluate the possibility of contamination in response to wall-rock assimilation.

No granodiorites were sampled as Longstaffe et al. (1980) and Chatterjee et al. (1985) provided several analyses of this 11thology which is remarkab1y unfform in terms of 1ts oxygen isotopic composition $\left(\delta^{18} 0-10.1-10.8 \%\right.$, N-13). Monzogranites with highly varlable proportions of biotite, muscovite and cordierite are represented by samples which are both proximal (No. 14: Turner tin) and distal (Nos. 9, 31, 53) to mineralized centres. Late-stage, medium-to fine-grained leucomonzogranites containing variable proportions of biotite and muscovite, also represent both barren (Nos. 17-1, 17-2, 39) and mineralized (Nos. $11-2,20,21,26-1,26-2,33,35,37 \mathrm{~A}$ ) areas. Samples of pegmatites formed at different stages of the evolution of the batholith were also taken. For example, the pegmatite from the Pockwock Lake area (No. 49) represents a small, local segregation within a biotite-muscovite-garnet monzogranite. In contrast, the Keddy's (Nos. 18, 19), Reeve's (No. 22C), Morley's (No. 38) and Grassy Brook (No. 25) pegmatite occurrences represent more evolved pegmatoids (based on the geochemistry of alkall feldspars, unpublished data of Kontak) which are associated with mineralized leucomonzogranites. The Long Lake (Nos. 34-1, 34A) and Walker moly (No. 11) pegmatites are associated with coarse quartz-Kfeldspar intergrowths, have banded aplite-pegmatite units, and are richly mineralized. A more detalled 


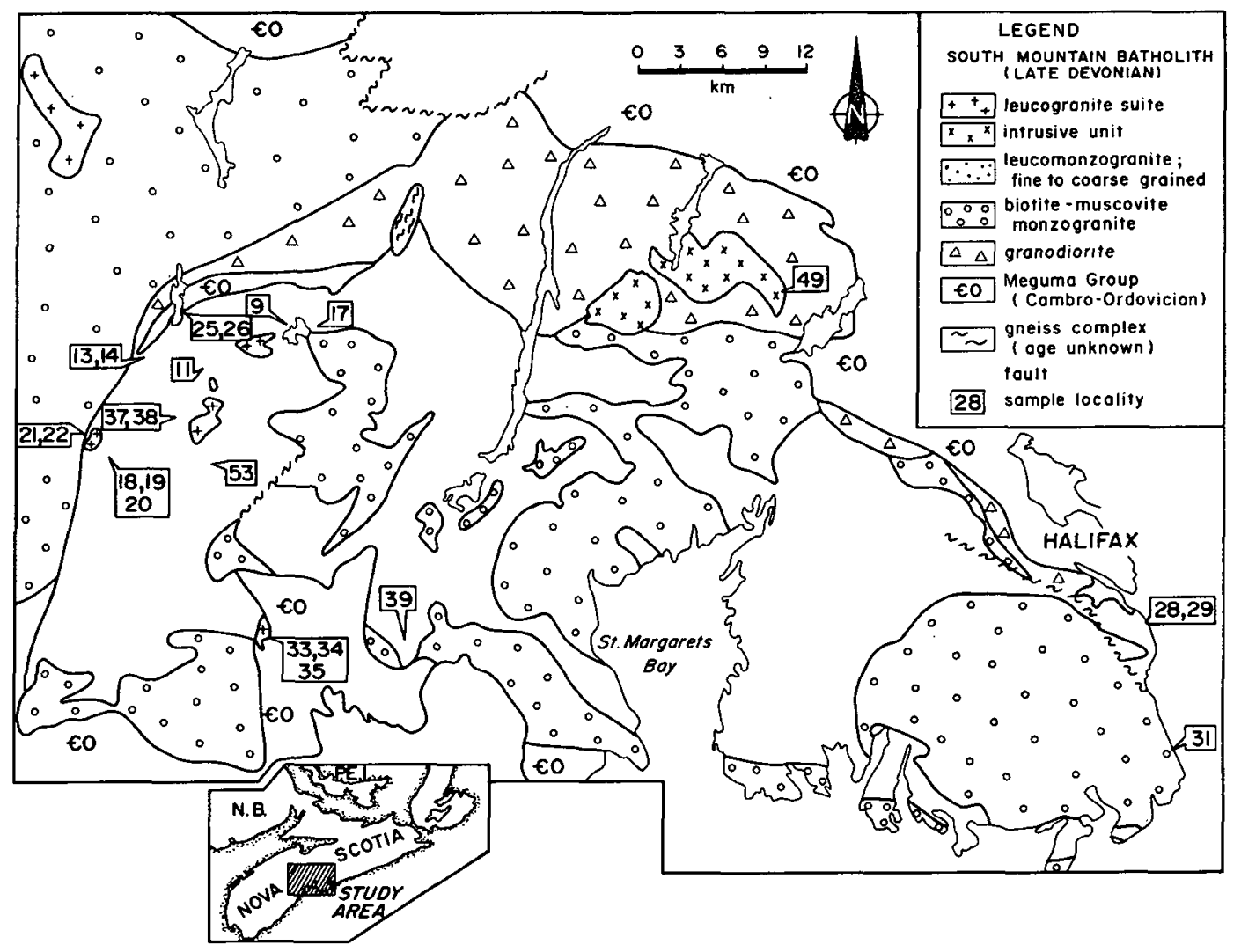

Fig. 1. Simplified geological map of the eastern part of the South Mountain Batholith (modified after MacDonald et al., 1987) showing sample localities.

account of these localities is provided by 0 'Re111y et al. (1982). Two zones of intense greisenization within a biotite-muscovite monzogranite from the southeastern part of the SMB are represented by samples 28 and 29.

The petrographic features of all the units discussed herein are described in detall by numerous previous workers (e.g., Charest, 1976; McKenzie, 1974; Logothet1s, 1984), so only the sallent aspects are discussed below.

The menzogranites are medium- to coarse-grained, have biotite > muscovite, contain coarse $\mathrm{K}$-feldspar megacrysts and may contain cordierite (e.g., No. 31). In thin section biotites characteristically contain abundant inclusions, the $\mathrm{K}$-feldspars (generally monoclinic variety) may contain relict plagloclase (1.e., from replacement), muscovite is of several textural varieties (see Ham and Kontak, this volume), plagloclase $\left(\mathrm{An}_{20-25}\right)$ is generally fresh, and $K$-feldspar is variabilyerthitic.

The leucogranites, fine- to medium-grained and texturally variable, are subdivided into two groups based on petrographic and chemical features (note also that group II leucogranites are associated with pegmatites). The most obvious difference between the groups is the presence of $1-2 \%$ biotite in the former group (note that in samples 33 and 35 chlorite is considered to have formed after biotite), whereas it is absent in group II and andalusite is an important constituent. Group I leucogranites contrast with the monzogranites in having fewer inclusions in blotite, which is also more commonly chloritized. In addition, plag1o- clase is more albitic in composition ( $\mathrm{An}_{0-10}$ ), zoning is rarely developed, and inclusions of secondary sericite and apatite are common. The $K-$ feldspar rarely contains perthite lamellae, and finer grained phases are typically microcline. In group II leucogranites many of the above features are also present, with the following additional observations: (1) plagloclase is mostly pure albite and contains numerous inclusions of secondary sericite and apatite; (11) muscovite is more abundant and 1ts texture ragged; and (111) andalusite may be quite abundant. The andalusite, of subhedral to anhedral shape, occurs as both isolated grains and also with mantles of muscovite. It is difficult to establish from textural criterla alone whether the andalusite is of magmatic or post-magmatic origin (cf. Clarke et al.. 1976).

We emphasize that the above features are broad generalizations, but they serve to illustrate that Important differences are readily apparent. Perhaps the most significant of these differences is that the more evolved rocks appear to have equilibrated with a fluid phase which is indicated by the presence of albite, alteration products in plagloclase, presence of microcline, texturally varlable muscovite, chloritization of biotite and the abundance of probably secondary andalusite.

\section{ANALYTICAL METHODS}

Sixteen whole rocks were analyzed for major and trace elements and REE (Tables 1 and 2). Major element analyses were obtained at Memorial 
Table 1. Whole Rock Geochemistry for Granitoids, South Mountain Batholith

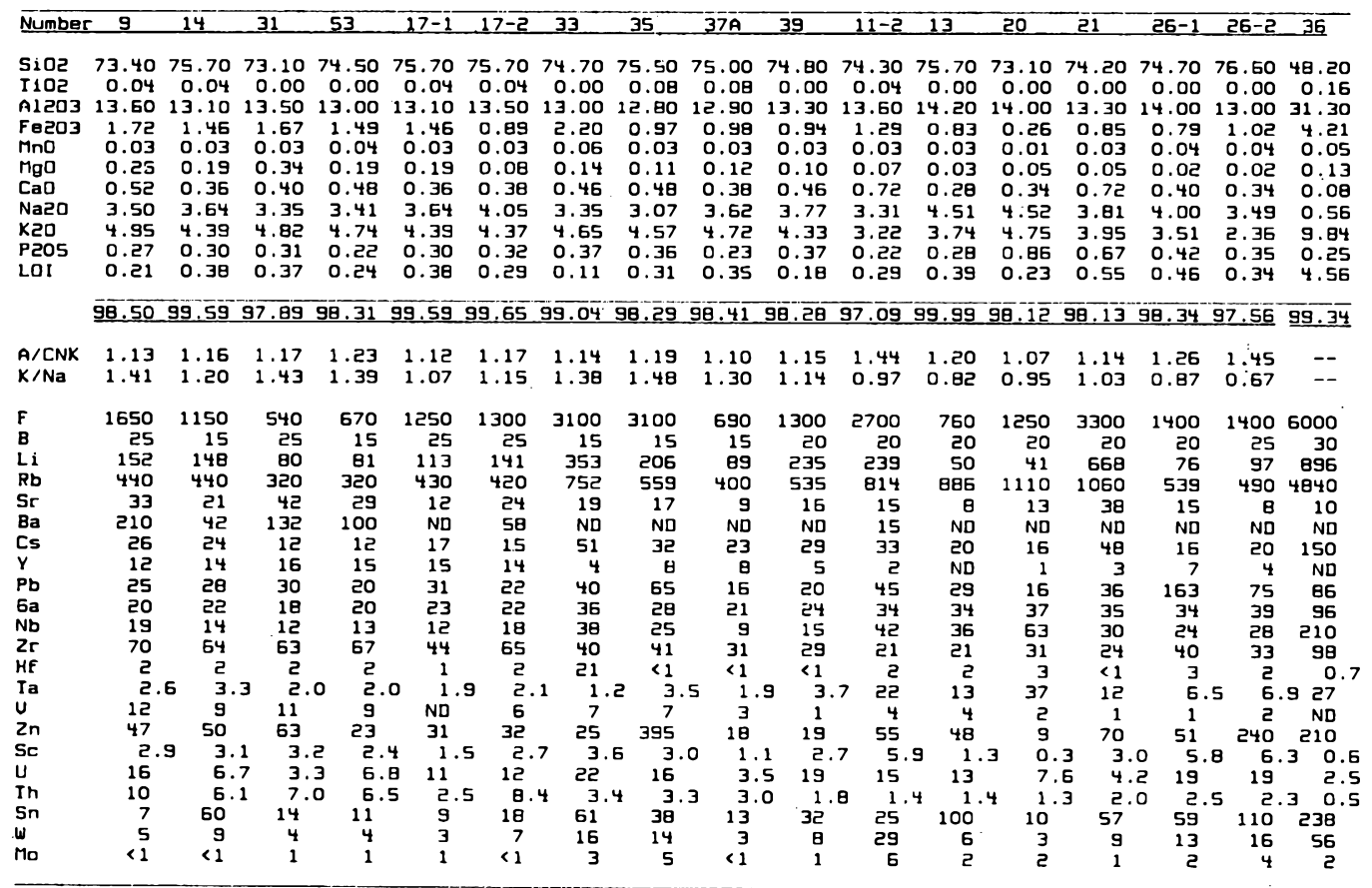

Samples analyzed are monzogranites (9, 14, 31, 53) group 1 leucogranites (17-1, 17-2, 33, 35, 37A, 39) and group II leucogranites (11-2, 13, 20, 21, 26-1, 26-2); number 36 is a muscovite separate from Morley's pegmatite.

LOI - Loss on Ignition

ND - not detected

Table 2. Rare Earth Element Chemistry for Granitoids, South Mountain Batholith
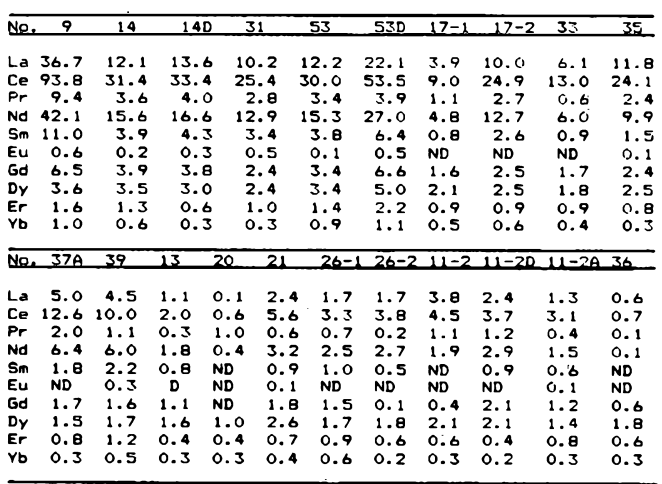

University. Newfoundland, employing wet chemical techniques combined with Atomic Absorption Spectrometry (AAS). Trace element abundances of $\mathrm{Rb}, \mathrm{Sr}, \mathrm{Cs}, \mathrm{Y}, \mathrm{Pb}, \mathrm{Ga}, \mathrm{Nb}, \mathrm{Zr}, \mathrm{V}$ and $\mathrm{Zn}$ were determined at Memorlal University. Newfoundland, on pressed whole-rock powder pellets using a fully automated Ph1111ps $1450 \mathrm{XRF}$ spectrometer, while F (specific 1on), B (plasma), I1 (AAS), Ag (AAS), Sc, Mo, Cs, Hf, Ta, W, Au, Th, U (all instrumental neutron activation) and $\mathrm{Sn}$ (XRF) were analyzed by Bondar-Clegg \& Company, Ottawa. The REB's were analyzed at Memorial University, Newfoundland, using the thin-film XRF technique of Fryer (1977).

Oxygen 1sotopic analyses (Table 3 ) of whole rocks (15) and mineral separates ( 8 quartz, $10 \mathrm{~K}$ -
Table 3. Oxygen Isotope Data for Granitoids of the South Mountain Batholith

\begin{tabular}{|c|c|c|c|c|}
\hline $\begin{array}{l}\text { Sample } \\
\text { No. }\end{array}$ & $\begin{array}{r}\text { Whole } \\
\text { Rock }\end{array}$ & Quartz & Muscovite & K-feldspar \\
\hline 9 & 11.1 & - & - & - \\
\hline 11 & - & 8.9 & 8.2 & 9.8 \\
\hline $11-2$ & 10.0 & - & - & - \\
\hline 13 & 3.6 & - & - & - \\
\hline 14 & 9.5 & - & - & - \\
\hline $17-1$ & 10.8 & - & - & - \\
\hline $17-2$ & 10.4 & - & - & - \\
\hline 18 & - & - & - & 10.6 \\
\hline 19 & - & - & - & 11.0 \\
\hline 20 & 10.7 & - & - & - \\
\hline 21 & 11.4 & - & - & - \\
\hline $22 \mathrm{C}$ & - & 11.4 & - & 11.4 \\
\hline 25 & - & 11.4 & - & 8.9 \\
\hline $2 b-1$ & 10.9 & - & - & - \\
\hline $26-2$ & 10.0 & - & - & - \\
\hline 28 & - & 18.2 & 12.0 & - \\
\hline 29 & - & - & - & 12.2 \\
\hline 31 & 11.0 & - & - & - \\
\hline 33 & 10.4 & - & - & - \\
\hline $34-1$ & - & 10.6 & - & 11.0 \\
\hline $34 A$ & - & 10.8 & - & 11.0 \\
\hline $37 A$ & 11.3 & - & - & - \\
\hline 38 & - & 11.6 & - & 10.0 \\
\hline 39 & 9.9 & - & - & - \\
\hline 49 & - & 11.3 & 8.8 & 11.6 \\
\hline 53 & 11.0 & - & - & - \\
\hline
\end{tabular}

feldspar, and 3 muscovite) were produced at the University of Saskatchewan employing conventional procedures for the 1sotopic analysis of silicates (see Clayton and Mayeda, 1963). Isotopic data are reported as $\delta{ }^{18} 0$ values in permil $(\delta / 00)$ relative to Standard Mean Ocean Water (SMOW) based on analysis of the NBS-28 laboratory standard. The overall reproductbility of $\delta^{18} 0$ values has averaged $\pm 0.18 \%(2 \sigma)$. 


\section{WHOLE-ROCK CHEMISTRY RESULTS}

\section{Major Elements}

The granites are all enriched in silica with 73.1 to 76.7 wt.\% $\mathrm{SIO}_{2}$. With respect to the cafemic elements, on1y $\mathrm{Mg}$ appears to define a clear pattern with decreasing values from the monzogranites through the leucogranite sultes. For $\mathrm{Ca}$ and $\mathrm{Fe}$ there is no clear trend which we attribute to the following:

(1) Fe, although most consistent1y enriched in the monzogranites, is elevated in other rocks due to the presence of minor sulphides and celadonitic muscovite.

(2) Ca is highly variable in the leucogranite and overlaps the values for the monzogranites $(0.36$ to 0.52 wt.\%). Much higher values of $\mathrm{Ca}$ in some of the leucogranites (up to $0.72 \mathrm{wt} . \%$ ) are due to the presence of fluorite and apatite which are inferred to be of secondary orlgin based on textural evidence.

Both $\mathrm{Mn}$ and $\mathrm{T} 1$ have low abundances (near or below detection limits) in all of the suites. There is general decrease in the $\mathrm{K}_{2} \mathrm{O}: \mathrm{Na}_{2} \mathrm{O}$ ratio from the monzogranites through to the letucogranite suites. This is commensurate with the change in plagioclase to more albitic composition.

Levels of phosphorous are similar in all sultes, except for sporadic enrichment in a few cases where apatite is present, as mentioned above. There is also a change in the peraluminous index of the suites from the monzogranites $(x-1.14)$, leucogranites I $(x-1.12)$ to leucogranites II $(x-1.26)$. In the latter sulte, samples with the higher A/CNK values (Nos. 11-2, 26-2) contain abundant andalusite; however, their lower total alkall contents suggest that some post-magmatic changes in the bulk composition of the samples may have occurred.

\section{Trace Elements}

The salient aspects of the trace element data, excluding the REE's, are summarized as follows:

E. B. L1: the volatile elements are generally all low (cf. Tischendorf (1977) for typical abundance levels in varlous granttold rocks). The highest $F$ values (ca. $3000 \mathrm{ppm}$ ) are found in the leucogranites, but these contrast, for example, with $F$ contents of about $1-2$ wt.\% ( $x-0.78 \pm 0.36, N-26)$ in leucogranites hosting the East Kemptville tin deposit (Kontak, 1987).

$\mathrm{Rb}$. Sr. Ba: these elements show covarlations typical of those expected from crystal fractionation processes (1.e., $\mathrm{Rb}$ increase; $\mathrm{Sr}$ and $\mathrm{Ba}$ decrease) operative in granitold systems (cf. McCarthy and Hasty, 1976). The low $\mathrm{Ba}$ and $\mathrm{Sr}$ contents in the leucogranites are perhaps worthy of comment. It is not possible to say whether these low values are due to real depletions as a result of extended differentiation or, alternatively, if the albitization of plagloclase may have caused liberation of the elements as the albite structure does not incorporate $\mathrm{Sr}$ or $\mathrm{Ba}$.

$\mathrm{K} / \mathrm{Rb}$ ratios of the three suites are quite distinctive (Fig. 2), and for the more evolved leucogranites the values correspond to the pneumatolytic field of Shaw (1968).

Cs. $\mathrm{Ga}$. $\mathrm{Nb}$. Ta: this group of incompatible elements shows general enrichment throughout the sequence of monzogranites to leucogranites, although Cs is erratically distributed compared to the other elements.

Zr. Hf: $\mathrm{Zr}$ shows a gradual depletion with progressive evolution of the suites and Hf is

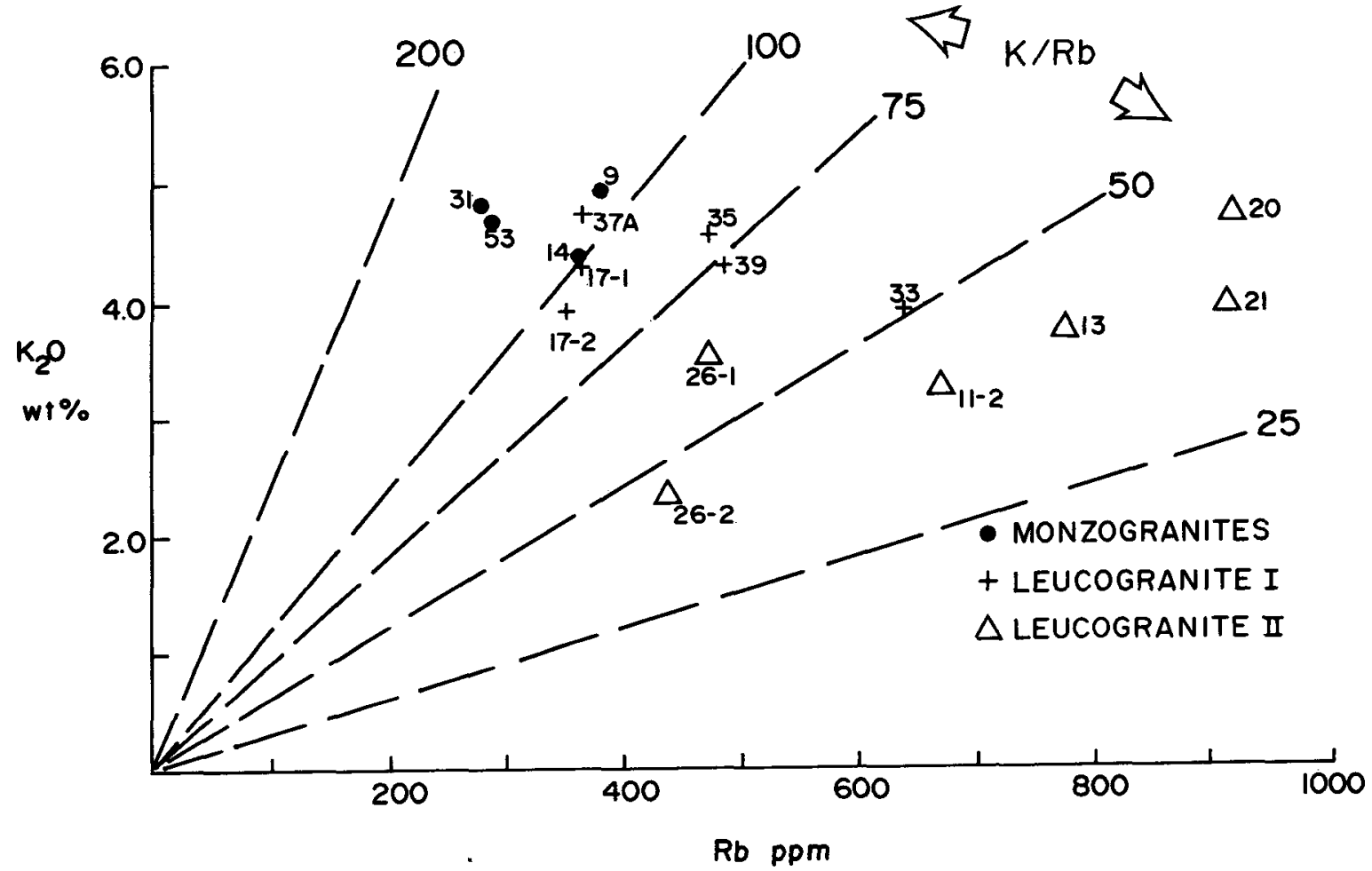

Fig. 2. K versus $\mathrm{Rb}$ plot for granites of the South Mountain Batholith. 
consistent1y 1ow; according1y, the $\mathrm{Zr} / \mathrm{Hf}$ rat10 diminishes.

U. Th: these two elements generally behave systematically throughout differentiation in the SMB (e.g. . Chatterjee and Muecke, 1982), but no consistent trends are apparent in these particular rocks (F1g. 3). Th values in the monzogranites $(x-7.4 \pm 1.5)$ are enhanced compared to the other rocks which generally have $<4 \mathrm{ppm} T \mathrm{Th}$, but $U$ behaves erratically and appears to have been mobile suggesting, perhaps, U mobility during a late hydrothermal overprinting event.

$\mathrm{Sn}$. W: both $\mathrm{Sn}$ and $\mathrm{W}$ are elevated above contents considered typical of magmatic values in low $\mathrm{Ca}$ granitold rocks in general (Turekian and Wedepoh1, 1961), with Sn more anomalous than $W$. The anomalous1y high Sn content of $60 \mathrm{ppm}$ for sample 14 is related to the proximity (1.e., in direct contact) of a late stage, fine-grained dyke (No. 13) which itself contains $100 \mathrm{ppm} \mathrm{Sn}$.

$\mathrm{Zr}$ vs $\mathrm{Nb}$ : $\mathrm{Ta}$ vs $\mathrm{Zr}$ : $\mathrm{Zr}$ vs $\mathrm{Rb}$ diagrams: in this series of varlation diagrams (F1g. 4) the different groupings of granitold rocks are clearly distinguished. The general trends are interpreted to reflect magmatic processes, except for the $\mathrm{Zr}$ versus $R b$ plot where a certain amount of the $R b$ enrlchment is probably due to orthomagmatic or even later hydrothermal activity. These diagrams clearly 1llustrate the progressive evolution of the groupings toward relatively more differentlated compositions with higher $\mathrm{Ta}$ and $\mathrm{Nb}$ abundances and lower $\mathrm{Zr}$ contents, and 1llustrate the retention of certain geochemical signatures diagnostic of the magmatic crystal fractionation of minerals such as zircon.

Rare Earth Elements: Chondrite-normalized REB patterns for all the rocks are presented in Figure 5. The monzogranites are characterized by LREB enrichment ( $\left.\mathrm{La}_{\mathrm{N}}-40-112\right)$, strong1y fractionated patterns ( $\left.\mathrm{La}_{\mathrm{N}} / \mathrm{Yb}-9-33\right)$, and moderately negative Eu anomalies (Eu/Eu* - 0.2-0.3); all features that have been recognized in other metaluminous to peraluminous granitold sultes. The patterns and absolute abundances (tota1 $10 \mathrm{REE}-110 \pm 53 \mathrm{ppm}$ ) are similar to those of monzogranites elsewhere in the SMB (Clarke and Muecke, 1981) and also to those of the Musquodobolt Batholith (MacDonald and Clarke, 1986).

Group I leucogranites have LREE's slightly depleted compared to the monzogranites ( $\mathrm{La}_{N}=10-$ 30), moderate1y fractionated patterns ( $\mathrm{La}_{\mathrm{N}} / \mathrm{Yb}_{\mathrm{b}}=5-$ 22), and moderate to extreme Eu depletion (Eu/Eu* $0.08-0.46$ to 0.01 ; note that some values are below detection limit (see Table 1)). The absolute abundances of the REE's (total $10 \mathrm{REE}-38 \pm 13$ $\mathrm{ppm})$ are also lower than those for the monzogranites.

Group II leucogranites are characterized by a further absolute depletion of the REE's (total 10 REE - $12 \pm 4 \mathrm{ppm})$, generally flat chrondritenormalized profiles ( $\mathrm{La}_{\mathrm{N}} / \mathrm{Yb}-0.5-9.2$ ) with a slight concave shape to the HREE portion. These patterns and abundances are similar to leucomonzogranites of the SMB reported in Clarke and Muecke (1981) and have been documented from the evolved phases of other grantic complexes (e.g., Nabalek 1986; Noyes et al. . 1983).

In a plot of total $R E E$ versus $K / R b$ (FIg. 6), the different granitic sultes are clearly distinguished, and such a plot 1llustrates we11

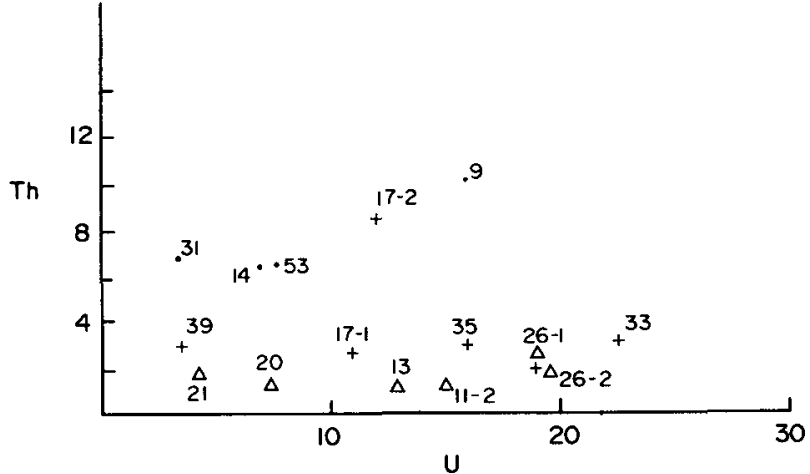

F1g. 3. Th versus U plot for granites of the South Mountain Batholith. Symbols as in Figure 2.
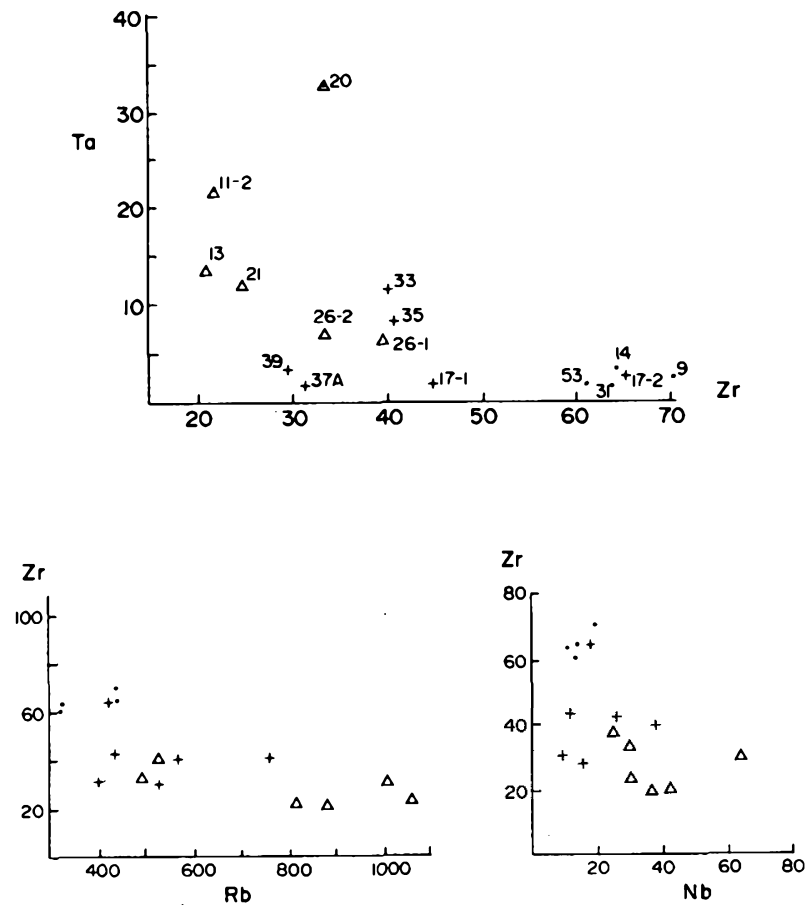

Fig. 4. Ta versus $Z r, Z r$ versus $R b$, and $Z r$ versus $N b$ plots for granites of the South Mountain Batholith. Symbols as in Figure 2.

the trend of progressive depletion of the REE's as the rocks become geochemically more evolved.

Comparing, therefore, the REB patterns for these three suites we note the following prominent features: (1) an overall depletion of the total REE's, due mainly to the decrease in the LREE abundances as $\mathrm{Yb}$ values are simflar for all the sultes; (2) a marked increase in the magnitude of the negative $\mathrm{Eu}$ anomaly within the leucogranite suites; and (3) a tendency for the HREB profile for the leucogranites (particularly Group II) to be concave.

\section{OXYGEN ISOTOPE RESULTS}

\section{Whole Rock Results}

Oxygen 1sotope data for 15 whole rock samples have a narrow range of $\delta^{18} 0$ values, regardless of distribution (1.e., proximity to granite-sediment 

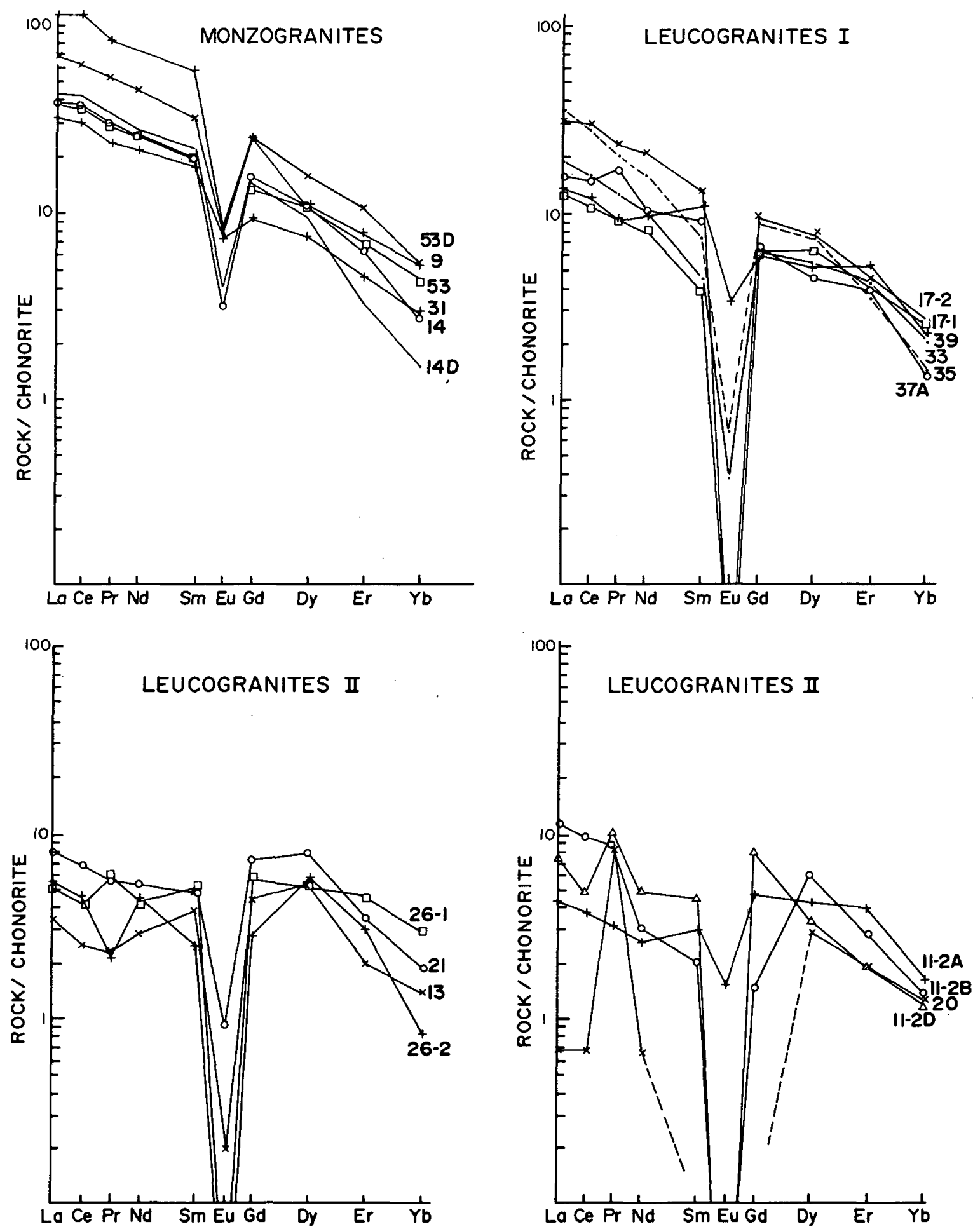

Fig. 5. Chondrite-normalized REE plots for granites of the South Mountain Batholith.

gontact). w1th a total range of between 9.5 to 11.3 $\%$ (mean of $10.6 \pm 0.5 \%$ ). There is no systematic variation of values corresponding to the groupings discussed above, nor with respect to geochemical indices of differentiation (e.g., $\mathrm{SHO}_{2}$ in Fig. 7). The only deviation from this homogeneity is an anomalous1y low value of $3.6 \%$ obtained for the fine-grained dyke rock from the Turner tin prospect. A value in this range neces-
sitates the involvement of a component of low water at some time in the post-magmatic history of this rock (e.g., Taylor, 1978).

The whole-rock data are similar to the results obtained by Longstaffe et al. (1980) and Chatterjee et al. (1985a) for the SMB granites and are also similar to data from other peraluminous, crusta1- 


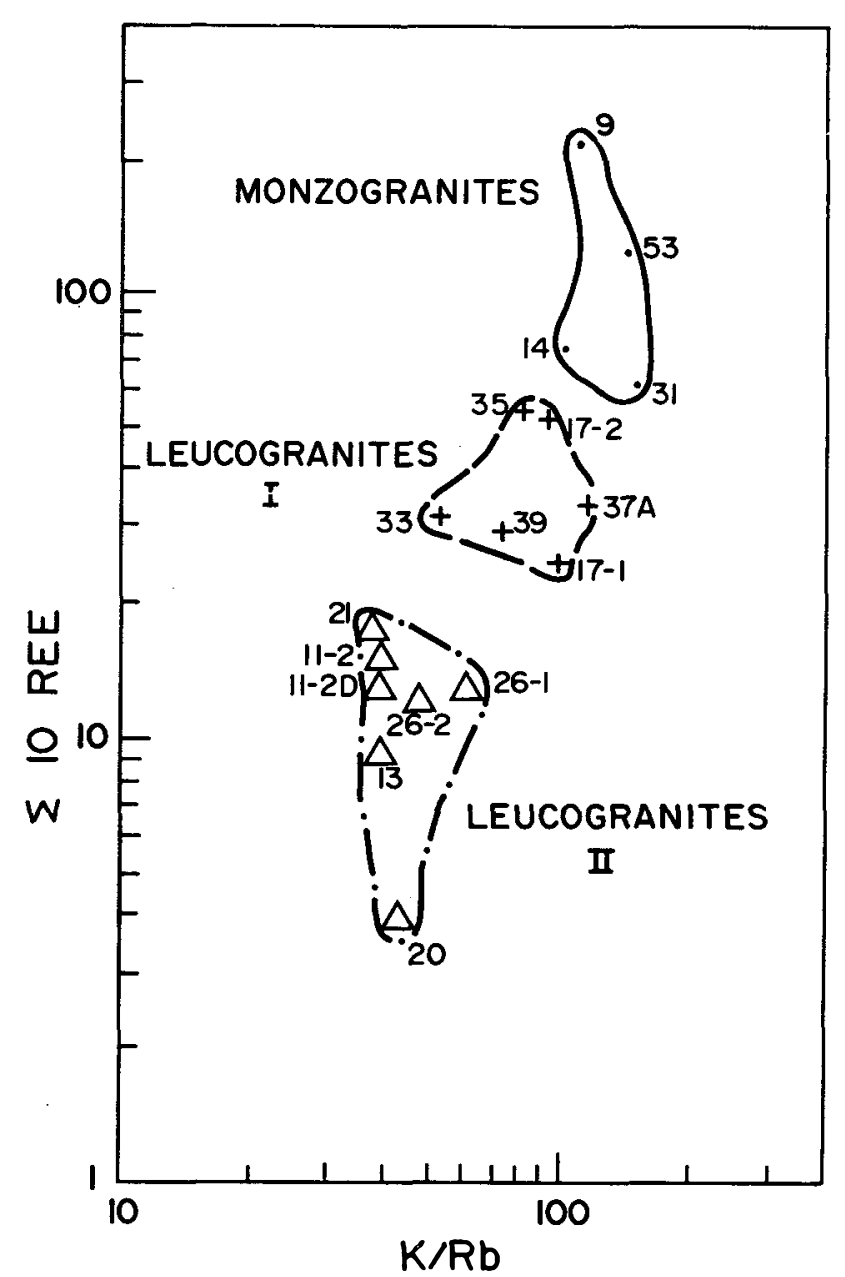

Fig. 6. K/Rb versus total REE plot for granites of the South Mountain Batholith. Symbols as in Figure 2.

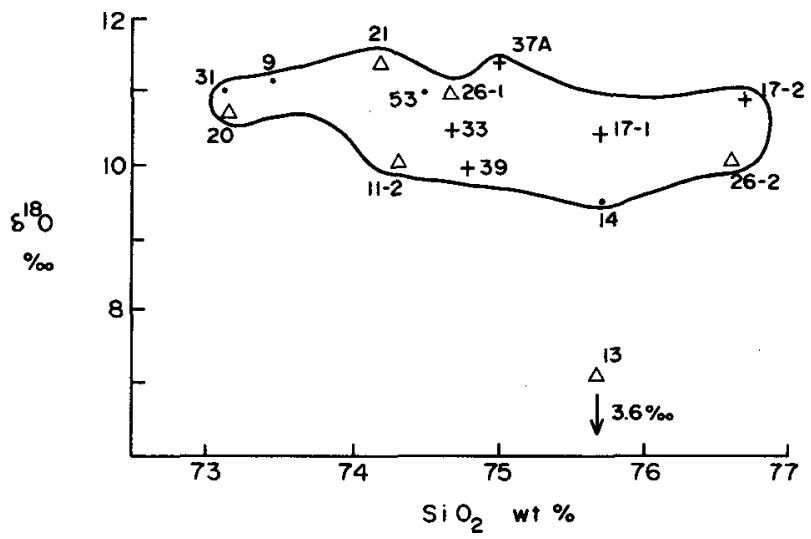

F1g. 7. Whole rock $\delta^{18} 0$ values versus wt.\% $\mathrm{S}^{10} \mathrm{p}_{\mathrm{p}} \mathrm{plot}$ for granites of the South Mountain Batholith. Symbols as in Figure 2.

derlved sultes throughout the world (see Sheppard, 1986) that have values of $10-14 \%$.

\section{Results for Mineral Separates}

Data for quartz, K-feldspar and muscovite are plotted in Figures 8 and 9 . There is a large varlation for minerals between the different localities despite the similarities of whole rock chemistry and oxygen isotope values referred to above. For example, among the pegmatitic occurrences the $\delta^{18} 0$ values for $\mathrm{K}$-feldspar are much more varlable $(8.9$ to $11.6 \%$ oo $)$ than the corresponding whole rock values $(10-11.3 \% / 00)$. In contrast, quartz, which is much more retentive of its primary $\delta^{18} 0$ value, shows a significantly smaller range of $10.4-11.6 \%$, with the only exception being a value of $9.9 \%$ for quartz from Walker moly. The two muscovites from the pegmatites gave similar results of 8.2 and 8.8 $8 / 00$.

Compared to the mineral data from Longstaffe et al. (1980), our data are similar for quartz and muscovite, but $\mathrm{K}$-feldspar contents are much more varlable (8.9-11.6\% versus $10.4-11.3 \%$ \% $/ 00$.

Two examples of greisen developed within a biotite-muscovite monzogranite (No. 31) form an 1sotopigally distinct population. Both quartz $(18.2 \%$ ) and muscovite $(12.0$ /80) from sample 28 are anomalousiy enriched in ${ }^{18} 0$ by $\sim 6 \%$ compared to the data for other pegmatites presented herein and granites in general. Simllarly, the Kfeldspar from a greisentzed pgnzogrante (No. 29) is also enriched, with a $\delta{ }^{18}$ value of $12.2 \%$.

For magmatic systems under conditions of 1sotopic equilibrium, quartz-K-feldspar and quartz-muscovite fractionations are $1 \pm 0.5 \%$ and $2.2-2.5 \%$, respectively (Taylor and Epstein, 1963; Taylor, $1968,1978)$. Of the three quartz-muscovite pairs analyzed, only sample 49 would appear to have retained magmatic equilibrium, and for the seven quartz-K-feldspar pairs only one (No. 38) has retained fractionations within the magmatic field. A plot of the quartz-feldspar data in Figure 9 further 1llustrates this point and indicates that for five samples the feldspars have been ${ }^{18} 0$ enriched, while one sample has been 0 depleted.

Also shown in Figure 9 are the data from Longstaffe et al. (1980). All of their samples correspond to the magmatic fleld and indicate that equilibrium has been maintained in the samples they studied.

\section{DISCUSSION}

The chemical and 1sotopic data presented for the granitic rocks are interpreted to represent a relatively simple evolution which can be accommodated by dominantly fractional crystallization processes \pm late aqueous fluld phase equilibria with a certain degree (the real extent cannot be demonstrated with the current data base) of late chemical modification due to hydrothermal activity. This case is best argued using elements such as $\mathrm{Nb}, \mathrm{Ta}, \mathrm{Zr}$ and the REB's which appear to have retained dominantly magmatic trends and patterns despite petrographic evidence indicating sporadic late-stage modification of the leucogranites by hydrothermal flulds. However, the enrichment of the leucogranites in some elements (e.g., Rb) and potential mobility of others (e.g., $U$. Th) Indicate that fluid-rock interaction was probably responsible for some, albelt not a great deal of, chemical change. Relevant to the study of felsic rocks in general, therefore, is the identification of the following parameters:

(1) determination of the boundary between magmatic (crystal- slicate melt \pm aqueous fluid 


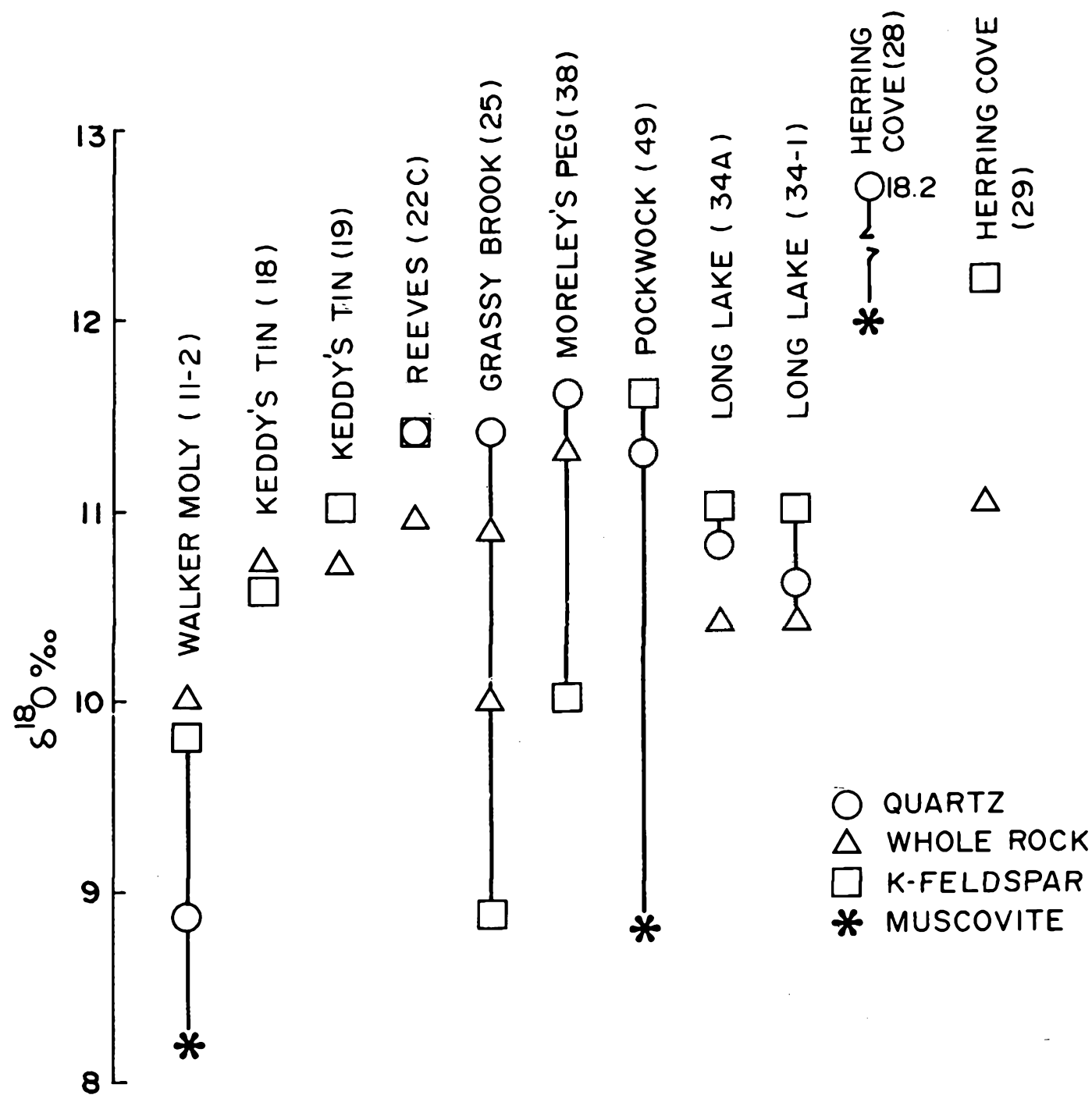

Fig. 8. $\delta^{18} 0$ values for mineral separates from pegmatites and greisens in the South Mountain Batholith.

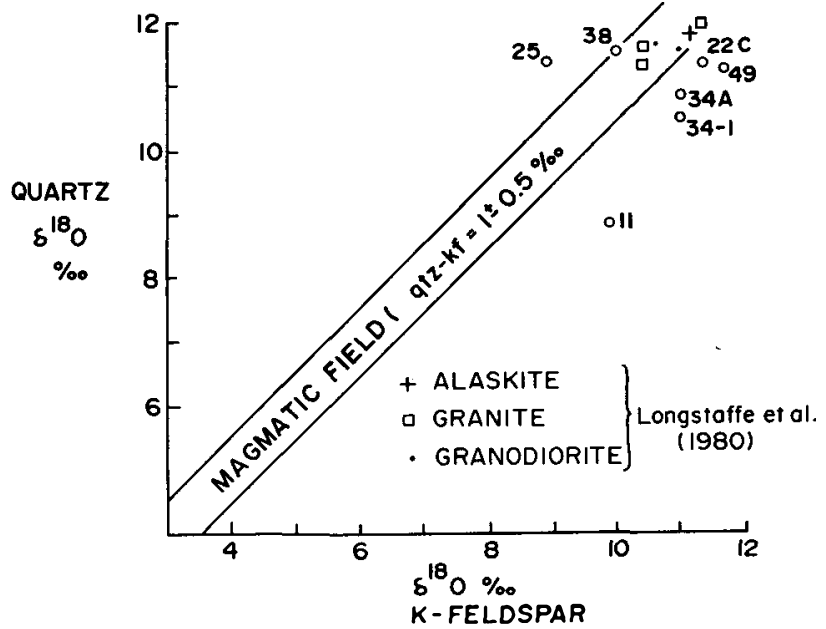

Fig. 9. $\delta^{18} 0$ quartz versus $\delta^{18} 0$ feldspar plot for mineral separates from pegmatites and greisens in the South Mountain Batholith. The magmatic trend represents quartz-feldspar fractionations calculated and measured for undisturbed plutonic igneous rocks. equilibria) and post-magmatic (fluid-rock equilibria) concentrations for elements that are particularly susceptible to hydrothermal enrichment and depletions;

(2) In the case where a late fluid phase has been active, the nature of the source reservotr (1.e., magmatic, meteoric, metamorphic). This, of course, has direct relevance to the origin of ore deposits.

Magmatic Versus Post-Magmatic Processes

The data presented herein for the granitic rocks define consistent trends for many elements, including those which are considered to be relatively immoblle (e.g., Pearce et al., 1984), despite the presence of essentially cryptic alteration which characterizes some of the geochemically more evolved rocks. Although we do not suggest that all the rocks owe their origin to a common 11quid line of descent, it does appear as if broadly comparable processes have been operative throughout a large part of the SMB (1.e., common magmatic historles). In order to examine more 
closely the role of crystal-sillcate melt versus fluid-rock \pm melt equilibria we will confine ourselves in this discussion to the REE profiles and abundances. However, we note that examination of the covariation of $\mathrm{Ba}$ versus $\mathrm{Sr}$ and $\mathrm{Rb}$ on $\log -$ log plots using our data and previously published data for the SMB indicate that fractional crystallization was the dominant petrological process during the evolution of the SMB (cf. McCarthy and Hasty, 1976; Cocherie, 1986).

The progressive decrease in the abundances of the REE (Figs. 5, 6) is due mainly to the LREE, a feature commonly observed in granitold rocks or felsic systems in general (M11ler and Mittlefeh1dt, 1982, 1984). Three potent1ally important processes are considered and evaluated, viz., 1iquid-state diffusion, aqueous fluid phase complexing, and crystal fractionation.

Liquid-state diffusion has been considered as a possible mechanism to explain the enhanced concentration of LILE and the decrease of LREE in high-silica rhyolites (H1ldreth, 1979, 1981) and granite systems (Ludington, 1981; Michae1, 1984; Tuach et al., 1986). The petrological features of the SMB do not resemble such systems and, therefore, it is unlikely that such processes played a very dominant role in the chemical evolution the this batholith.

F1ynn and Burnham (1978) demonstrated experimentally that the LREE can be complexed by a C1-bearing aqueous fluld phase and Taylor and Fryer (1982, 1983) and Taylor et al. (1981), among others, applied these results to natural situations. In the case of the SMB there is 1ittle field or petrographic evidence to suggest that a fluid phase was important during the progression from granodioritic to monzogranitic suites. Thus, it is unlikely that the LREE patterns are related to stripping due to C1-complexes via expulsion of an aqueous fluid phase from the melt during fractionation. However, the leucogranite suites may represent a different situation which we discuss in further detall below.

The ability of crystal fractionation processes to account for the progressive depletion of LREB in felsic systems is supported by the high partition coefficients thath have been measured for accessory mineral phases such as monazite, xenotime. allanite, sphene and apatite (e.g.. Gromet and Silver, 1983; Sawka et al., 1984; Jeffries, 1985). The presence of monazite, xenotime and apatite as inclusions within biotite and the decrease in $Y$ from monzogranites to leucogranites in the SMB is consistent with a model in which the LREB depletion is related to fractionation of such minerals (see more detalled discussion by Miller and Mittlefeh1dt, 1982, 1984; M1ttlefeh1dt and Miller, 1983).

The leucogranite sultes contrast with the monzogranites (also granodiorites, see Clarke and Muecke, 1981) in having distinctly concave patterns for the MREE-HREE. This is particularly noticeable in the group II leucogranites where the maxima in the chondrite-normalized patterns occur at Gd-Dy. Accompanying this marked change in the fractionation of the MREE and $\mathrm{HREE}$ is a flattening of the LREE profiles to $<10 \times$ chondrites. Although further depletion of the LREE may be accounted for by continued fractionation of accessory minerals, the similar $Y$ contents of the group $I$ and II leucogranites suggest that an alternative mechanism, or combination of processes, may be required. The close proximity of group II leucogranites to pegmatites indicates that a fluld phase was exsolved from the melts and, thus, its affect on the REE patterns and abundances should be considered.

The ability of $\mathrm{C} 1$ to form stable complexes with LREE at magmatic temperatures provides a viable means to account for the type of REE patterns observed here. There is ample petrographic evidence indicating that aqueous fluids have interacted with the rocks, and the proximity of pegmatites indicates that a fluid phase did indeed exist. Thus, we consider the observed LREE depletion in group II leucogranites to be a result of fluid stripping, perhaps accompanying pegmatite development.

The concave patterns recorded in the REE profiles of group II leucogranttes (Gd to $\mathrm{Yb}$ ) may also be accounted for by the evolution of a fluid phase. These patterns are similar to published REE profiles for fluorite (Strong et al., 1984; Clarke and Muecke, 1981; Chatterjee et al., 1985b; Marchand et al., 1976) and, therefore, the role of F complexing is considered a reasonable explanation. The peak of the REE profile at Gd-Dy suggests relatively dilute concentrations of $F$ in the melt/fluid and that monofluoric complexes were dominant (Strong et al., 1984). That F-bearing fluids were important in complexing the RER's is further demonstrated by a REB profile (Fig. 10) for a F-rich $(6000 \mathrm{ppm})$ muscovite (analysis 36 in Tables 1 and 2) from Morley's pegmatite. The concave shape of the MREE-HREE is almost 1dentical to that observed in the leucogranites. The enhanced $\mathrm{Rb}$ content (4840 ppm) of this muscovite also raises the possibility that some of the enrichment/depletion of this and other alkall elements in the leucogranites may be due to postmagmatic fluid-rock interaction.

We conclude, therefore, that on the basis of the REB distribution that there is an important

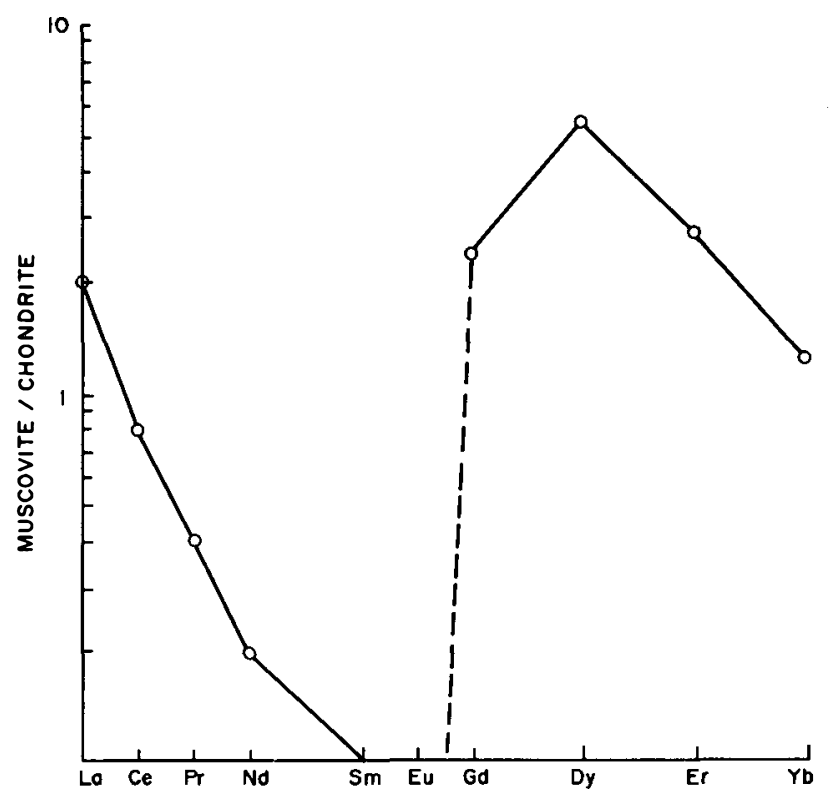

Fig. 10. Chondrite-normalized REE plot for muscovite separate from Morley's pegmatite. 
transition from the progressive differentiation sequence granodiorite-monzogranite-leucogranite (I) which is dominated by silicate melt-crystal equilibria, to group II leucogranites. The latter appears to have involved, in addition to meltcrystal equilibria, an important component of aqueous fluid-phase equilibrla. Although the role of a fluid phase is perhaps most easily recognized using the REE, the model calculations of Nabalek (1986) in a similar rock suite indicate that other trace element contents (e.g.. Rb, Ba, Sr) would also be affected quite drastically. We note, therefore, that on $10 \mathrm{~g}-10 \mathrm{~g}$ plots of $\mathrm{Ba}$ versus $\mathrm{Rb}$ and $\mathrm{Sr}$ the data for the leucogranites fall off the crystal fractionation trend defined by the data for the more mafic assemblages. Thus, because of the probable involvemnt of a fluid phase during the late-stage magmatic evolution of the SMB, we are hesistant in assigning a crystal-melt equilbria origin to many of the trace elements in the more evolved phases.

\section{Source of Fluids and Post-Magmatic Disequilibrium}

The use of oxygen 1sotopes permits one to identify the presence and affects of fluids of different derivations in lgneous rocks (e.g., Taylor, 1978). The similarity of the whole-rosk oxygen isotopic values for all the granitolds examined in this study, in addition to those of Longstaffe et al. (1980) and Chatterjee et al. (1985a), Indicates at first sight that 11ttle modification of the primary oxygen isotopic signatures has occurred. In fact, the quartzfeldspar pairs and other mineral data of Longstaffe et al. (1980) indicate that oxygen isotopic equilibrium existed during magmatic crystallization and that the original isotopic character of these minerals has not been modified by post-magmatic processes. In contrast, the mineral data from a 1imited number of pegmatites and greisens suggest disequilibrium caused by late- to post-magmatic processes.

Discussing first the whole rock data, we note that there is no systematic variation of the $\delta{ }_{0}$ composition of the granites and that combining the data from all sources (1.e.. Longstaffe et al., 1981; Chatferjee et al., 1985; this study) gives an average $\delta{ }^{\circ}$ composition of $10.77 \pm 0.67 \%$ (N-54) for the SMB. The tight cluster and lack of any obvious relationship beteen ${ }^{18} 0$ values and indices of differentiation inidicates that the granitic magmas most 11kely evolved as a closed system (cf. Taylor, 1978). However, the observed range of $1.8 \%$ is in excess of that which can be related to crystal fractionation processes over such a small silica range (Taylor and Sheppard, 1986) and thus an alternative explantation is required. Because there is 1ittle compeliling evidence to favour assimilation of Meguma Group lithologies ( ${ }^{18} 0$ of $11.6 \pm 0.9, \mathrm{~N}-31$ : Longstaffe et al., 1980) as the cause of this varlation (see Clarke and Halliday. 1980 for further discussion), we instead interpret the range in oxygen isotopic data as reflecting heterogeneity in the source region.

Focusing on the oxygen 1sotope data for mineral separates (Figs. 8, 9), we have noted that disequilibrium fractionations are recorded.
Because of the tendency of feldspar to reequilibrate more readily than quartz at low temperatures, the shift of the data out of the magmatic fiefo in Figure 9 is attributed to exchange of ${ }^{18} 0$ between an aqueous fluid and feldspar at low temperatures. The $\delta^{18} 0$ composition of the fluids involved in this re-equilibration is estimated using mineral-water fractionations ( $\mathrm{Fig}$. 11). Although a range of $400-600^{\circ} \mathrm{C}$ is indicated for quartz in Figure 11, the higher temperature is considered more realistic and indicates a $\delta^{10} 0$ of 9-10 $/ 00\left(500-600^{\circ} \mathrm{C}\right)$ for the fluld. In contrast, the feldspars are interpreted to have exchanged with a fluid phase to lower temperatures based on their strongly perthitic textures and partial inversion to triclinic structures (unpublished $\mathrm{X}$ ray diffraction data of Kontak). For temperatures of $400-500^{\circ} \mathrm{C}$, the $\delta^{18} 0$ of the fluid in equilibrium with feldspar is 7-9 $/ 00 / 18$ Thus, the inferred range $(7-10 \% / 00)$ of the $\delta^{18} 0$ composition of the fluids based on both feldspar and quartz mineralwater fractionations is consistent with a magmatic reservour, although a component of metamorphicderfved filuld cannot be excluded (Ohmoto, 1986).

In contrast, the $\delta^{18} 0$ composition of the fluid responsible for greisen formation is markedly different ( $\mathrm{F} 1 \mathrm{~g}$. 11). For sample $\$ 28$ a $\delta^{18} 0$ value of $11.5-14 \%$ is calculated based on quartz-water fractionation for a temperature of $300-400^{\circ} \mathrm{C}$. The enrichment of the fluid in ${ }^{18} 0$ indicates a certain component of elther metamorphic-derived water or fluid which equilibrated isotopically with the nearby metasedimentary rocks. The feldspar in sample $\# 29$ appears to have retained more of its primary magmatic signature compared to quartz in sample $\|_{28}$, as the calculated $\delta{ }^{18} 0$ of the fluid is 7-10 /00 for a similar temperature interval. The difference between these two greisens may be related to a much higher fluid-rock ratio in the former which resulted in complete conversion of the feldspar to a quartz-muscovite assemblage. Converse1y. fluids with different oxygen 1sotopic signatures may have been involved.

\section{CONCLUSIONS}

A combined petrological and oxygen 1sotopic study of a suite of grantold rocks in the SMB of Nova Scotia has revealed the following:

(1) The chemical evolution of the SMB is best accommodated by crystal-melt equilibrium processes in the ear1y, less evolved members. However, in the more fractionated rocks, represented by leucogranites of the New Ross area spatially associated with pegmatites, chemical signatures (e.g.. REE patterns) indicate that fluid-me1t equilibria were also important.

(2) The LREE depletions observed in granites of the SMB are attributed to fractionation of accessory mineral phases, but fluid stripping was also an important process in the most evolved rocks. The concave profiles observed for the MREEHREE part of chondrite-normalized diagrams in the most fractionated rocks are attributed to $F$ complexing via interaction of melts with a Fbearing aqueous fluid phase.

(3) The abundances of many trace elements, particularly the alkalis ( $\mathrm{Rb}, \mathrm{Sr}, \mathrm{Ba}$ ), in the fractionated suites are due to a combination of processes involving both magmatic and post-magmatic 
TEMPERATURE ${ }^{\circ} \mathrm{C}$

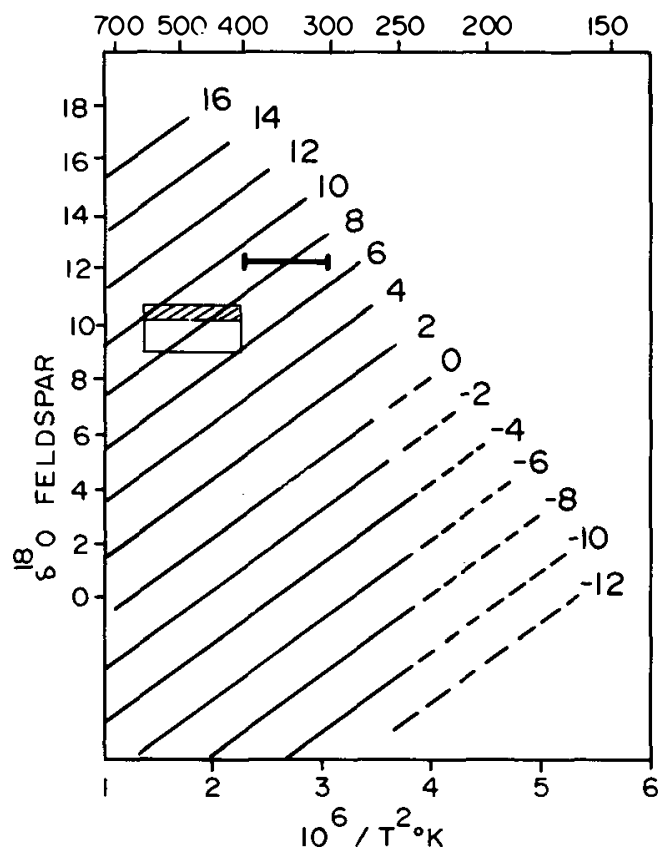

TEMPERATURE ${ }^{\circ} \mathrm{C}$

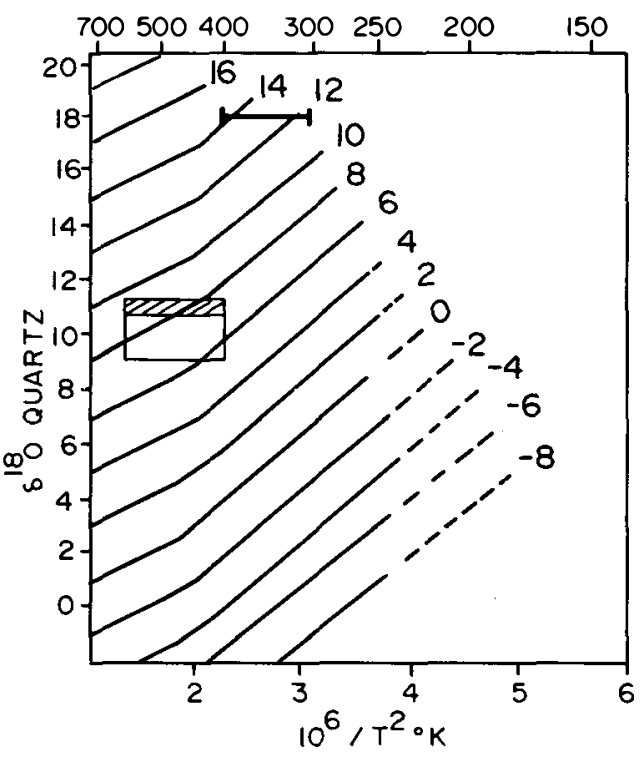

Fig. 11. $\delta^{18} 0$ feldspar and quartz versus temperature plots showing oxygen-isotope data for feldspars and quartz. The temperature ranges are discussed in the text. The family of 1 ines represents the $\delta 180$ of $\mathrm{H}_{2} \mathrm{O}$ in equilibrium with feldspar and quartz at given $\delta 180$ for specific temperatures. Dashed lines indicate fractionations extrapolated to below the limits of equilibration. The upper part of the boxes contain most of the data and are the areas used for calculating the $\delta 180$ values of the fluid discussed in the text. Calculations based on the fractionation factors (minera1-water) of Clayton et al. (1972) and $0^{\prime} \mathrm{Nell}$ and Taylor (1967) for quartz and K-feldspar, respectively.

\section{contributions.}

(4) There is no measureable difference between the oxygen isotopic signatures of the major 11thologic units of the SMB regardless of the degree of fractionation, proximity to country rock or presence of late-magmatic or early post-magmatic fluid interaction. The whole rock $\delta^{18} 0$ values (9.5-11.4 \% /00) are similar to those in other strongly peraluminous suites world wide and indicate a large component of crustal material in the genesis of the granites. The observed varlation in $\delta 0$ values is due to heterogeneity in the source region.

(5) Oxygen 1sotopic values of mineral separates from pegmatitic sultes indicate that equilibrium fractionations were not maintained. This is attributed to $10 \mathrm{w}$ temperature (1.e., to $400^{\circ} \mathrm{C}$ ) exchange of feldspars with cooling fluids of magmatic derivation. In contrast, isotopic signatures in greisens reflect interaction with a component of metamorphic-derived fluid.

\section{ACKNOWLEDGEMENTS}

This research was funded through NSERC grants to D.F. Strong and R. Kerrich, and D.J. Kontak acknowledges financial support in the form of a post-doctoral fellowshlp through funds from D.F. Strong (NSERC Grant No. A7975). Part of this research was also funded by the Nova Scotla Department of Mines and Energy through the CanadaNova Scotia Mineral Development Agreement. Field work in Nova Scotia was supported by the Nova Scotia Department of Mines and Energy and D.J.K wishes to especlally thank the SMB crew for providing accommodation and fleld support. The major element chemistry was capab1y done by G. Andrews, the trace elements by $G$. Velnott and the REE's by P. Moore. Technical services of the Nova Scotia Department of Mines are acknowledged for having drafted the figures. R. P. Taylor and an anonymous reviewer are also acknowledged for critically reading the manuscript.

BURNHAM, C.W. 1979. Magmas and hydrothermal flu1ds. In Geochemistry of Hydrothermal Ore Deposits. Edited by H. L. Barnes. J. Wiley and Sons, New York. pp. 71-136.

CHAREST, M.H. 1976. Petrology, geochemistry and mineralization of the New Ross area, Lunenburg County, Nova Scot1a. M.Sc. thesis, Dalhousie University. Hallfax, Nova Scot1a, $192 \mathrm{p}$.

CHATTER JEE, A.K., and MUECKE, G.K. 1982. Geochemistry and the distribution of uranium and thorium in the granitold rocks of the South Mountain Batholith. Nova Scotia: some genet1c and exploration 1mplications. In Uranium in Granites. Edited by $\mathrm{Y}$. T. Maurice. Geological Survey of Canada. Paper 81-23, pp. $11-17$.

CHATTERJEE, A.K., and STRONG, D.F. 1984. Rare-earth and other element varlations in greisens and granites associated with East Kemptville tin deposit, Nova Scot1a, Canada. Transactions Inst1tute of Mining and Metallurgy. 93. pp. B59B70.

CHATTERJEE, A.K., STRONG, D.F., CLARKB, D.B., ROBERTSON, J. PLLLOCK, D., and MUECKB, G.K. 1985A. Geochemistry of the granodiorite hosting uranium mineralization at Millet Brook. In Gulde to the Gran1tes and Mineral Deposits of Southwestern Nova Scotia. Edited by A. K. Chatterjee and D. B. Clarke. Nova Scot1a Department of Mines and Energy, Paper 85-3, pp. 64-114.

CHATTERJEE, A.K., STRONG, D.F., and CLARKB, D.B. 1985B. Petrology of the polymetallic quartz-topaz greisen at East Kemptvilie. In Guide to the Gran1tes and Mineral Deposits of Southwestern Nova Scot1a. Editod by A.K. Chatterjee and D.B. Clarke. Nova Scotia Department of Mines and Energy. Paper 853. Pp. 156-196.

CLARKE, D.B., and BALLIDAY, A.N. 1980. Stront1um 1sotope geology of the South Mountain Batholith. Nova Scotia. Geochimica et Cosmochimica Acta, 44, pp. 1045-1058.

CLARKE, D.B. . MCKENZIR, C.B., MUECKB, G.K., and RICHARDSON, S.W.

1976. Magmatic andalusite from the South Mountain Batholith. 
Nova Scotia. Contributions to Mineralogy and Petrology. 56. pp. $279-287$

CLARKE, D.B. . and MUECKR, G.K. 1981. Geochemical evolution of the South Mounta1n Bathol1th, Nova Scot1a: rare-earth-element evidence. Canadian Mineralogist, 19, pp. 133-146.

CLARKE, D.B., and MUECKE, G.K. 1985. Review of the petrochemistry and origin of the South Mountain Batholith and assoclated plutons. Nova Scotla, Canada. In High Heat Production Granites, Hydrothermal Circulation and Ore Genesis. Inst1tute of Mining and Metallurgy, London, pp. 41-54.

CLAYTON, R.N.. and MAYEDA, T.K. 1963. The use of bromine penta-fluoride in the extraction of oxygen from oxddes and silicates for 1sotopic analysis. Geochimica et Cosmochimica Acta, 27, pp. 43-52.

CLAYTON, R.N., O'NEIL, J.R., and MAYEDA, T.K. 1972. Oxygen 1sotope exchange between quartz and water. Journal of Geophysical Research, 77, pp. 3057-3067.

COCHERIB. A. 1986. Systematic use of trace element distribution patterns in log-log diagrams for plutonic suites. Geochimica et Cosmoch1mica Acta, 50, pp. 2517-2522.

FLYNN, R.T., and BURNHAM, C.W. 1978. An experimental determination of rare earth partition coefficients between a chloride containing vapour phase and silicate melts. Geochimica et Cosmochimica Acta, 42, pp. 685-701.

FORD, K.L. and O'RBILLY, G.A. 1985. A1rborne gamma-ray spectrometric surveys as an indicator of granophile element specialization and associated mineral deposits in the granitic rocks of the Meguma Zone of Nova Scot1a, Canada. In High Heat Production Granites, Hydrothermal Circulation and Ore Genesis. Institute of M1ning and Metallurgy, London, Pp. 113-134.

FRYER, B.J. 1977. Rare-earth evidence in iron formations for changing Precambrain oxidation states. Geochimica et Cosmoch1mica Acta, 41, pp. 361-367.

GROMBT, L.P.. and SILVER, L.T. 1983. Rare earth element distributions among minerals in a granodiorite and their petrogenetic implications. Geochimica et Cosmochimica Acta. 47. pp. $925-939$.

HIGH HEAT PRODUCTION GRANITES, HYDROTHERMAL CIRCULATION AND ORE GENESIS 1985. Institute of Mining and Metallurgy, London, 593

HILDRETH, W. 1979. The B1shop Tuff: evidence for the origin of compositional zonation in silicic magma chambers. Geological Society of Amer1ca, Spec1al Paper 180, pp. 43-75.

HILDRETH, W. 1981. Gradients in silic1c magma chambers: 1mplications for 11thospheric magmat1sm. Journal of Geophysical Research, 86, DP. 10153-10192.

JEFFRIES, N.L. 1983. The distribution of the rare earth elements within the Carnmenellis Pluton, Cornwall. Mineralogical Magazine, 49, pp. 495-504.

KONTAK, D.J. 1987. East Kemptville leucogranite: a possible mid-Carboniferous topaz granite. In Nova Scot1a Mines and Mineral Branch Report of Act1vities for 1986. Edited by J.L. Bates and D.R. MacDonald. Nova Scot1a Department of Mines and Energy. Report 87-1, pp. 81-94.

KONTAK, D.J., and COREY, M.C. 1988. Metasomat1c origin for spessartine-rich garnet in the South Mountain Batholith. Nova Scotia. Canadian Mineralogist, 26.

KUBILIUS, W.P. 1983. Sulphur 1sotop1c evidence for country rock contamination of granitolds in southwestern Nova Scotia. M.Sc. thes1s, Pennsylvania State University, $103 \mathrm{p}$

LOGOTHETIS, J. 1984. The mineralogy and geochemistry of metasomat1zed gran1to1d rocks from occurrences in the South Mounta1n Batholith. New Ross area, southwestern Nova Scot1a. M.Sc. thes1s, Dalhousie University, Halifax, Nova Scot1a, 359

LONGSTAFFB, F.J.. SMITH, T.E., and MUEHLENBACHS, K. 1980. Oxygen 1sotope evidence for the genesis of Upper Paleozo1c granito1ds from southwestern Nova Scot1a: Canadian Journal of Earth Sc1ences, 17, pp. 132-141.

LUDINGTON, S. 1981. The Redskin Gran1te: evidence for thermogravitational diffusion in a Precambrian granite batholith. Journal of Geophysical Research, 86. pp. 1042310469.

MACDONALD, M.A., and CLARKB, D.B. 1985. The petrology. geochemistry and economic potential of the Musquodobolt Batholith. Nova Scot1a. Canadian Journal of Earth Sc1ences. 22. pp. 1633-1642.

MACDONALD, M.A. COREY, M.C., HAM, L.J., and HORNE, R.J. 1987. South Mountain Batholith project: progress report. In Mines and Mineral Branch Report of Activities 1987. Part A. Edited by J.L. Bates and D.R. MacDonald. Nova Scot1a Department of Mines and Energy, Report 87-5, pp. 99-104.

MANNING. D.A.C. and EXLEY. C.S. 1984. The origins of latestage rocks in the St. Austell gran1te - a re-1nterpretation. Journal of the Geological Soc1ety of London, 141, pp. 581-591.

MARCHAND, L. , JOSEPH, D. , and THOURAY. J.C. 1976. Criteres d'analyse geochemique des gisement de fluorine bases sur etude de la distribution des lanthanides - application au gite de Ma1ne. Mineralium Deposita, 11, pp. 357-379.

MCCARTHY, T.S., and HASTY. R.A. 1976. Trace element distribution patterns and the1r relationsh1p to the crystallization of eranitic melts. Geochimica et Cosmochimica Acta, 40, pp. $1351-1358$.

MCKENZIB, C.B. 1974. Petrology of the South Mountain Batholith, western Nova Scot1a. M.Sc. thesis, Dalhousie University. Halifax, Nova Scot1a, 101 p.

MCKENZIE, C.B. and CLARKE. D.B. 1975. Petrology of the South Mountain bathol1th. Nova Scot1a. Canadian Journal of Earth Sc1ences, 12, pp. 1209-1218.

MICHARL, P.J. 1984. Chemical differentiation of the Cordillera Paine granite (southern Chile) by in situ fractional crystallization. Contributions to Mineralogy and Petrology. 87. PD. 179-195.

MILLER, C.F., and MITTLEFEHLDT, D.W. 1982. Depletion of 11ght rare-earth elements in felsic magmas. Geology, 10. pp. 129133.

MILLER, C.F., and MITTLEFEHLDT, D.W. 1984. Extreme fractionation in felsic magma chambers: a product of 11quidstate diffusion or fractional crystallization? Earth and Planetary Sc1ence Letters, 68, pp. 151-158.

MITTLBFEHLDT. D.W., and MILLER, C.F. 1983. Geochemistry of the Sweetwater Wash Pluton, California: Implications for "anomalous" trace element behavior during differentiation of felsic magmas. Geoch1mica et Cosmochimica Acta, 47, pp. 109124 .

NABALEK, P.I. 1986. Trace-element modelling of the petrogenesis of granophyres and aplites in the Notch Peak granitic stock, Utah. American Mineralog1st, 71, pD. 460-471.

NOYES, H.J., FREY, F.A., and WONES, D.R. 1983. A tale of two plutons: geochemical evidence bearing on the origin and differentiation of the Red Lake and Eagle Peak plutons. Central S1erra Nevada, Callfornia. Journal of Geology, 91, pp. $487-570$.

OHMOTO. H. 1986. Stable 1sotope geochemistry of ore deposits. In Stable Isotopes in High Temperature Geological Processes. Edited by J.W. Valley, H.P. Taylor Jr.. and J.R. O'Ne11. Mineralogical Society of America, Reviews in Mineralogy. 16. pp. 491-559.

O'NEIL, J.R., and TAYLOR, H.P...Jr. 1967. The oxygen 1sotope and cation exchange chemistry of feldspars. American Mineralog1st. 52, pp. 1414-1437.

O'REILLY, G.A., FARLEY, E.J., and CHAREST. M.H. 1982. Metasomat1c-hydrothermal mineral deposits of the New RossMahone Bay area. Nova Scot1a. Nova Scotia Department of Mines and Energy, Paper 82-2, $96 \mathrm{p}$.

PEARCE, J.A., HARRIS, N.B.W., and TINDLE, A.G. 1984. Trace element discrimination diagrams for the tectonic interpretation of granitic rocks. Journal of Petrology, 25. pp. $956-983$

SAWKA, W.N. . CHAPPELL, B.W., and NORRISH, K. 1984. L1ght-rareearth-element zoning in sphene and allanite during granitold fractionation. Geology, 12, pp. 131-134.

SHAW. D.M. 1968. A review of K-Rb fractionation trends by covarlance analysis. Geochimica et Cosmochimica Acta, 32, pp. 573-601.

SHEPPARD, S.M.F. 1986. Igneous Rocks: III Isotopic case studies of magmat1sm in Africa, Eurasia and Oceanic Islands. In Stable Isotopes in High Temperature Geologic Processes. Edited by J.W. Valley, H.P. Taylor Jr., and J.R. O'Ne11. Mineralogical Society of America, Reviews in Mineralogy, 16. pp. $319-371$

SMITH, T.E., PECK, D. , HUANG, C.H., and HOLM, P.E. 1986. A reappraisal of the alaskite/muscovite-biotite granite suite of Halifax County, Nova Scotia. Maritime Sediments and Atlantic Geology, 22, pp. 101-116.

STONE, M. and EXIBY, C.S. 1986. H1gh heat production granites of southwest England and their associated mineralization: a review. Transactions Institute of Mining and Metallurgy, 93 pp. B25-B36.

STRONG. D.F. 1981. Ore deposit mode1s - 5. A model for granoph1le mineral deposits. Geoscience Canada, 8, pp. 155161

STRONG. D.F., and CHATTERJER, A.K. 1985. A review of some chemical and mineralogical characteristics of gran1told rocks hosting $\mathrm{Sn}$, W, U, Mo deposits in Newfoundland and Nova Scotia. In High Heat Production Granites, Hydrothermal Circulation and Ore Genesis. Institute of Mining and Metallurgy. London, pp. 489-516.

STRONG, D.F. . FRYER, B.J., and KERRICH, R. 1984. Genes1s of the St. Lawrence fluorospar deposits as indicated by fluid inclusion, rare earth element and 1sotope data. Economic Geology. 79. pp. 1146-1158.

TAYLOR, H.P. Jr. 1968. The oxygen 1sotope geochemistry of Igneous rocks. Contributions to Mineralogy and Petrology, 19, 
pp. $1-71$.

TAYLOR, H.P. Jr. 1978. Oxygen and hydrogen 1sotope studies of plutonic granitic rocks. Earth and Planetary Science Letters, 38. pp. $177-210$.

TAYLOR, H.P.. Jr., and EPSTEIN, S. 1963. $0^{18} / 0^{16}$ ratios in rocks and coexisting minerals of the Skaergaard intrusion. Journal of Petrology. 4. pp. 51-74.

TAYLOR, H.P., Jr., and SHEPPARD, S.M.F. 1986. Igneous rocks: I. Processes of 1sotop1c fractionation and 1sotope systematics. In Stable Isotopes in High Temperature Geolog1cal Processes. Edited by J.W. Valley, H.P. Taylor Jr. and J.R. O'Ne11. Mineralogical Soc1ety of America, Reviews in Mineralogy, 16. pp. 227-273.

TAYLOR, R.P., and FRYER, B.J. 1982. Rare earth element geochemistry as an ald to interpreting hydrothermal ore deposits. In Metallization Assoclated with Ac1d Magmatism. Edited by A.M. Evans. J. Wiley \& Sons, Ch1chester, 6. Pp. 357-366.

TAYLOR, R.P., and FRYER, B.J. 1983. Rare earth element 11thogeochemistry of granito1d mineral deposits. Canadian Institute of Mining and Metallurgy, 76. pp. 74-84.

TAYLOR, R.P. and STRONG, D.F. editors. 1985. GraniteRelated Mineral Deposits: Geology. Petrogenesis and Tectonic Sett1ng. Extended Abstracts of Papers, Canadian Inst1tute of Mining and Metallurgy Conference. Hallfax. Nova Scot1a, 289 p. TAYLOR, R.P., STRONG, D.F. , and FRYER, B.J. 1981. Volat1le control of contrasting trace element distributions in peralkaline granitic and volcanic rocks. Contributions to Mineralogy and Petrology. 77, pp. 267-271.

TISCHENDORF, G. 1977. Geological and petrographic character1stics of silicic magmatic rocks with rare element mireralizat1on. In Metallization Associated with Ac1d Magmat1sm. Bdited by M. Stemprok, L. Burnol, and G. T1schendorf. Geological Survey of Czechoslovak1a, Prague, 2, pp. 41-96.

TUREKIAN, K.K., and WEDEPOHL, K.H. 1961. Distribution of the elements in some major units of the earth crust. Geological Society of America Bulletin, 72, pp. 175-192. 